\title{
Meningkatkan Kemampuan Berhitung Melalui Media Congklak Pada Siswa Kelas II SD Inpres Wosia
}

\author{
Alice Yeni Verawati Wote ${ }^{1}$ Mardince Sasingan $^{2}$, Yunita Kasiang \\ ${ }^{123}$ Pendidikan Guru Sekolah Dasar, Fakultas Keguruan dan Ilmu Pendidikan, Universitas Halmahera
}

\author{
ARTICLEINFO \\ Article history: \\ Received 18 Desember \\ 2019 \\ Received in revised form \\ 30 Desember 2019 \\ Accepted 15 Januari 2020 \\ Available online 20 \\ Februari 2020

\section{Kata Kunci:} \\ Kemampuan Berhitung, \\ Media Congklak \\ Keywords: \\ Ability on Counting, \\ Congklak Media
}

\begin{abstract}
A B S T R A K
Tujuan dari penelitian ini adalah untuk mengetahui Penerapan Media Permainan Congklak dalam Meningkatkan Kemampuan Berhitung Siswa Kelas II SD Inpres Wosia. Metode dalam penelitian ini yaitu metode pre-experiment tanpa adanya kelompok pembanding. Penelitian ini mengunakan One Group Pretest-Posttest Design dengan teknik analisis data menggunakan paired $t$ test. Teknik pengumpulan data yang digunakan adalah soal tes. Penelitian ini menggunakan keseluruhan populasi yang berjumlah 24 orang siswa. Hasil penelitian menunjukkan perbedaan rata-rata diperoleh nilai posttest $=77.91$ lebih tinggi dibandingkan nilai pretest $=43.75$, sedangkan thitung $=-14.697 \neq \mathrm{t}_{\text {tabel }}=1.714$. Maka dapat disimpulkan $\mathrm{H}_{0}$ ditolak dan $\mathrm{H}_{\mathrm{a}}$ diterima atau penerapan media permainan Congklak dapat meningkatkan kemampuan berhitung siswa Kelas II SD Inpres Wosia.
\end{abstract}

\section{A B S T R A C T}

The objective of this study is to know the implementation of "Congklak Game" Media for Increasing Ability on Counting of The Second Grade of Inpres Wosia Elementary School Students. The methode used in this study is pre-experiment methode without any comparison group. This research used One Group Pretest-Posttest Design with data analysis technique using paired $t$ test to measure students' ability on mathematical counting through "Congklak" media. Data gathering technique used is answering questions test. Data population used is all 24 students in the class. Result of the study showed that the margin of average marks of posttest $=77.91$ which is higher than average marks of pretest $=43.75$ whereas $t_{\text {hitung }}=-14.697 \neq t_{\text {tabel }}=1.714$. So it can be concluded that $H_{0}$ is not relevant and $H_{a}$ is accepted which means implementation of "Congklak Game" media can be useful to increase the ability on counting of The Second Grade of Inpres Wosia Elementary School Students.

Copyright (C) Universitas Pendidikan Ganesha. All rights reserved.

\section{Pendahuluan}

Dalam mewujudkan tujuan pendidikan nasional sebagaimana diatur dalam UU No. 20 Tahun 2003 tentang Sistem Pendidikan Nasional, perlu dilakukan berbagai upaya strategi untuk mendukung penyelenggaraan program pendidikan. Kesempatan untuk memperoleh pendidikan yang bermutu dimulai dari usia dini sampai dengan perguruan tinggi. Untuk mencapai semua itu, guru yang memiliki tanggung jawab membimbing dan mengajar untuk menjadikan siswa sebagai manusia yang beriman dan bertaqwa terhadap Tuhan Yang Maha Esa, dan berbudi pekerti luhur, memiliki pengetahuan dan keterampilan, kesehatan jasmani dan rohani, pribadi yang mantap dan mandiri serta rasa tanggungjawab kemasyarakatan dan kebangsaan. Namun selama ini guru masih berperan penuh dalam proses pembelajaran tanpa memberikan keseempatan kepada siswa untuk berdiskusi maupun mengeluarkan ide-ide kreatif mereka. Banyak kajian yang menyatakan bahwa media dan metode pembelajaran yang pasif tidak efektif bagi siswa (Michel, dkk, 2009).

Dengan demikian akan lebih baik apabila guru dalam proses pembelajaran menggunakan media dan metode pembelajaran yang tepat agar siswa mampu mengingat dan memahami materi yang diajarkan oleh guru. Menurut Djamarah (2011), guru adalah salah satu unsur manusia dalam proses pendidikan.

${ }^{1}$ Corresponding author.

E-mail addresses:alicewote23@gmail.com¹(Alice Yeni Verawati Wote); mardincesasingan88@gmail.com² (Mardice); Yunita Kasiang408@gmail.com³ (Yunita) 
Unsur manusia lainnya adalah siswa. Guru dan siswa berada dalam proses interaktif, guru yang mengajar dan mendidik sedangkan siswa yang belajar pelajaran dari guru. Jadi dapat disimpulkan bahwa guru adalah orang yang bertanggungjawab memberikan ilmu pengetahuan dan keterampilan kepada siswa.

Siswa pada usia sekolah dasar, bermain merupakan dasar dan sumber energi bagi perkembangan mereka. Pada saat guru dan siswa bermain bersama-sama, siswa akan menjadi bersemangat dan diwaktu yang sama pula siswa mengarahkan energinya untuk memilih melakukan aktivitas belajarnya. Hal senada juga dituliskan oleh H Spencer (Muksin, 2006) dalam teori Surplus Energy yaitu bermain sangat bermanfaat untuk mengisi kembali energi seorang siswa yang telah melemah. Setelah siswa puas bermain, mereka akan merasakan semangat kembali untuk melakukan aktivitasnya. Teori Practive For Adulthood (K. Gross dalam Muksin, 2006) menyatakan pengetahuan siswa sangat penting fungsinya bagi mereka pada saat menjelang dewasa kelak. Melalui bermain, siswa dapat mengembangkan kreativitasnya. Dan bagi siswa yang sudah mulai muncul kreativitasnya, mereka akan terus mengembangkan kreativitasnya lagi. Dari uraian di atas, disimpulkan bahwa melalui media permainan dapat memberikan dampak yang positif bagi peningkatan kemampuan belajar siswa. Misalnya, media permainan Congklak bisa melatih kecerdasan kinestetik dan melatih kecerdasan logika matematika.

Menurut Pupuh Fathurrohman, dkk (2014), media diartikan sebagai sesuatu yang dapat membawa informasi dan pengetahuan dalam interaksi yang berlangsung antara guru dan siswa. Media dalam pembelajaran matematika dapat diartikan sebagai suatu perangkat benda nyata yang dirancang, dibuat dan disusun secara sengaja oleh guru untuk membantu siswa memahami materi pembelajaran matematika. Media pembelajaran dapat memudahkan guru untuk menjelaskan keabstrakkan dan kerumitan materi pembelajaran berhitung dalam matematika. Namun pemilihan media pembelajaran haruslah dapat mendukung tujuan pembelajaran yang telah dirumuskan, karena bila media yang digunakan tidak sesuai maka media tersebut akan menjadi penghambat dalam proses pembelajaran berhitung. Salah satu media yang dapat mendukung tercapainya proses pembelajaran matematika adalah permainan congklak.

Permainan congklak merupakan permainan tradisional yang tumbuh dan berkembang di masyarakat Indonesia hingga saat ini. Namun, keberadaannya sudah berangsur-angsur mengalami kepunahan di era 4.0. Siswa sekarang ini lebih banyak memilih gadget sebagai permainannya, padahal permainan congklak memiliki banyak manfaat dalam mengasah kecerdasan siswa. Pada umumnya, permainan congklak dimainkan dengan cara mengisi atau membagi lubang pada setiap papan congklak dengan biji-bijian dan tidak boleh terlewati atau terisi lebih dari satu.

Permainan congklak memiliki aspek-aspek perkembangan pada siswa, yaitu psikomotorik (melatih kemampuan motorik halus), emosional (melatih kesabaran dan ketelitian), kognitif (melatih kemampuan menganalisa dan menyusun strategi), sosial (menjalin kontak sosial dengan teman bermain), serta melatih jiwa sportifitas siswa (Heryanti dalam Prima Nataliaya, 2015). Menurut Morena Cindo (2010), congklak merupakan permainan tradisonal yang dapat melatih anak dalam kecakapan berhitung. Sama halnya dengan kurniawati (2006), bahwa permainan congklak merupakan permainan yang menitikberatkan pada kemampuan berhitung. Oleh karena itu, permainan congklak lebih tepat untuk diterapkan sebagai media pembelajaran, karena siswa akan bersemangat dan lebih aktif berlajar sesuai dengan tahap perkembangan dalam menunjang kemampuan berhitung, dengan memanfaatkan benda-benda konkret.

Dengan media permainan congklak, hal-hal yang dianggap abstrak oleh siswa dapat disajikan dalam bentuk permainan untuk memberikan kebebasan dalam mengkonstuk pemikiran dan temuan selama melakukan aktivitas belajar. Hal ini sesuai dengan teori Pigeat (Zubaidah Amir, dkk, 2006), bahwa pada awalnya siswa sekolah dasar belajar melalui hal-hal yang konkret. Tahap operasi konkret 7 - 11 tahun dinyatakan dengan perkembangan sistem pemikiran yang didasarkan pada peristiwa-peristiwa yang langsung dialami siswa. Siswa sekolah dasar masih menerapkan logika berpikir pada barang-barang yang konkret, belum bersifat abstrak maupun hipotesis. Siswa dapat melihat, meraba, mengungkapkan dengan pemikiran secara langsung objek yang sedang mereka pelajari, sehingga konsep abstrak yang baru dipahaminya itu akan mengendap, melekat, dan tahan lama bila siswa belajar melalui berbuat, bukan hanya mengingat. Artinya, pada tahap ini guru dapat memulai pembelajaran matematika berawal dari halhal yang nyata kemudian barulah mengaitkan ke materi matematika yang bersifat abstrak. Bruner (Asep Hidayat, 2016), mengemukakan bahwa dalam proses belajar mengajar siswa berkembang melalui tiga tahap perkembangan mental yaitu tahap enaktif, tahap ikonik dan tahap simbolik. Pada tahap enaktif, siswa secara langsung terlihat menggunakan atau memanipulasi objek-objek konkret secara langsung dalam mempelajari matematika. Dalam tahap ikonik, kegiatan siswa menyangkut mental dan merupakan gambaran dari objek-objek konkret, dan tahap simbolik merupakan tahap memanipulasi simbol-simbol secara langsung dan tidak ada lagi kaitannya dengan objek-objek. Teori Brownwell berpendapat bahwa salah satu cara bagi siswa untuk mengembangkan pemahaman tentang matematika adalah dengan menggunakan benda-benda tertentu ketika mereka pempelajari konsep matematika (Asep Hidayat, 
2016). Dengan demikian, media permainan congklak sangat diperlukan untuk mempermudah siswa memahami materi matematika yang bersifat abstrak menjadi konkret, lebih khusus pada peningkatan kemampuan berhitung siswa.

Berdasarkan uraian di atas, maka peneliti tertarik melakukan penelitian dengan judul: Meningkatkan Kemampuan Berhitung Melalui Media Permainan Congklak pada Siswa Kelas II SD Inpres Wosia.

Tujuan dari penelitian ini untuk mengetahui penerapan media permainan congklak dalam meningkatkan kemampuan berhitung pada siswa Kelas II di SD Inpres Wosia.

\section{Metode}

Metode yang digunakan dalam penelitian adalah pre-eksperiment dengan rancangan desain penelitian yaitu one group pretest dan posttest hanya menggunakan satu kelas yaitu kelas eksperimen tanpa adanya kelompok pembanding. Populasi penelitian adalah seluruh siswa Kelas II SD Inpres Wosia. Teknik penarikan sampel adalah teknik sampling jenuh atau keseluruhan populasi digunakan sebagai sampel yaitu 24 orang siswa Kelas II SD Inpres Wosia. Sedangkan tahap penelitiannya yaitu: 1) pretest; 2) pembelajaran mengunakan media permainan congklak; 3) posttest; 4) menganalisis data hasil pretest dan posttest. Instrumen atau alat ukur yang digunakan adalah soal tes dan teknik analisis data yang digunakan adalah Paried $t$ Test.

\section{Hasil dan Pembahasan}

Data hasil penelitian kemampuan sebelum diberi perlakuan (pretest) dan sesudah diberi perlakuan (posttest) yang telah dianalisis melalui statistik deskriptif yang disajikan dalam tabel sebagai berikut:

Tabel 01. Rangkuman Hasil Analisis Statistik Deskriptif

\begin{tabular}{lll}
\hline Analisis & $\begin{array}{l}\text { Data Hasil test } \\
\text { Pretest }\end{array}$ & Posttest \\
\hline Banyaknya data (n) & 24.00 & 24.00 \\
Minimum & 10.00 & 50.00 \\
Maximum & 80.00 & 100.00 \\
Mean & 43.75 & 77.91 \\
Median & 45.00 & 80.00 \\
Modus & 40.00 & 75.00 \\
Std. Deviation & 182.60 & 251.13 \\
\hline
\end{tabular}

Berdasarkan analisis pada tabel 1 , diperoleh rata-rata nilai posttest siswa $=77.91$ lebih tinggi dibandingkan nilai pretest siswa $=43.75$. Maka dapat disimpulkan bahwa terdapat peningkatan kemampuan berhitung melalui media congklak pada siswa Kelas II SD Inpres Wosia sebesar $77.91 \%$.

Selanjutnya peneliti melakukan uji normalitas dan hipotesis penelitian. Hasil uji tersebut adalah sebagai berikut:

\section{Uji Normalitas}

Hipotesis yang diajukan dalam uji normalitas data adalah:

$\mathrm{H}_{0}$ : Data yang tidak berdistribusi normal

$\mathrm{H}_{\mathrm{a}}$ : Data yang berdistibusi normal

Kriteria pengujian : tolak $\mathrm{H}_{0}$ jika nilai Asymp sig $<\alpha=0,05$. Hasil pengujian uji normalitas data penelitian dengan menggunakan One-Sample Kolmogorov-Smirnov Test termuat pada Tabel 02 dibawah ini.

Tabel 02. Rangkuman Hasil Pengujian Normalitas

\begin{tabular}{lll}
\hline One-Sample Kolmogrov-Smirnov Test & Asymp.Sig & Alpha \\
\hline Pretest & 0.72 & 0.05 \\
Posttest & 0.89 & 0.05 \\
\hline
\end{tabular}


Berdasarkan tabel di atas dapat disimpulkan bahwa data pretest dan Posttest berdistribusi normal atau menerima $\mathrm{H}_{\mathrm{a}}$ (nilai Asymp sig $>\alpha$ ).

\section{Uji Hipotesis Penelitian}

Hipotesis statistic dapat dirumuskan sebagai berikut:

$\mathrm{H}_{0}=\mu_{1}=\mu_{2}$

$\mathrm{H}_{\mathrm{a}}=\mu_{1} \neq \mu_{2}$

Tabel 03. Hasil Uji Paried $t$ Test

\begin{tabular}{lllll}
\hline Kelompok & $\mathrm{N}$ & $\mathrm{T}$ & $T_{\text {tabel }}$ & Sig. \\
\hline Eksperimen & 24 & -14.697 & 1.714 & 0.01 \\
\hline
\end{tabular}

Kriteria pengujian : ditolak $\mathrm{H}_{0}$ jika $t_{\text {hitung }}=\mathrm{t}_{\text {tabel }}$ diterima $\mathrm{H}_{\mathrm{a}}$ jika $\mathrm{t}_{\text {hitung }} \neq \mathrm{t}_{\text {tabel. }}$. Berdasarkan hasil analisis menggunakan paried $t$ Test diperoleh hasilnya adalah $t_{\text {hitung }}=-14.697$ dan $t_{\text {tabel }}=1.714(\mathrm{dk}=23, \alpha$ $=0,05)$. Dari hasil perhitungan diperoleh nilai diperoleh $t_{\text {hitung }}=-14.697 \neq \mathrm{t}_{\text {tabel }}=1.714$. Maka $\mathrm{H}_{0}$ ditolak atau $\mathrm{H}_{\mathrm{a}}$ diterima, yang berarti Penerapan Media Congklak dapat Meningkatkan Kemampuan Berhitung Siswa Kelas II SD Inpres Wosia.

Berdasarkan hasil analisis ditemukan bahwa media congklak dapat meningkatkan kemampuan berhitung siswa kelas II SD Inpres Wosia. Hal ini dikarenakan guru menggunakan media permainan congklak dalam pembelajaran berhitung, sehingga pembelajaran menjadi lebih menyenangkan dan lebih mudah dipahami oleh siswa. Pembelajaran yang dilakukan oleh guru dengan menggunakan media congklak mampu memberikan kesempatan bagi siswa untuk menggunakan material bermain guna melatih kemampuan berhitung siswa.

Melalui penggunaan media permainan congklak membuat siswa menjadi senang dan menambah semangat siswa dalam melaksanakan aktivitas belajar. Dengan adanya media permainan proses pemebajaran akan lebih menyenangkan dan suasana kelas jadi lebih menyenangkan. Manfaat penggunaan media congklak yaitu dapat membantu siswa untuk mengenal dan memahami dasar pengembangan kemampuan berhitung siswa. Artinya semakin efektifnya penggunaan media congklak maka semakin tinggi kemampuan belajar siswa.

Hasil penelitian tersebut di atas sama dengan pendapat dari Heryanti (Prima Nataliaya, 2015), media permainan congklak memiliki aspek-aspek perkembangan pada anak, yaitu melatih kemampuan motorik halus, kesabaran dan ketelitian, kemampuan menganalisa, menyusun strategi, menjalin kontak sosial dengan teman bermain, dan melatih jiwa sportifitas siswa. Itu berarti media yang tepat untuk diterapkan dalam mengembangkan kemampuan berhitung permulaan pada anak dilakukan dengan permainan-permainan yang menyenangkan, suasana belajar yang menggembirakan dan bagaimana anak tertarik untuk belajar, sehingga kemampuan kognitif siswa dapat meningkat.

Penelitian tersebut di atas juga menunjukan efektivitas penggunaan media permainan congklak dapat meningkatkan kemampuan berhitung siswa Kelas II SD Inpres Wosia. Hal ini ditunjukan dengan adanya peningkatan rata-rata kemampuan berhitung siswa Kelas II SD Inpres Wosia setelah diberikan perlakuan dengan menggunakan media congklak dan dites (posttest,) dibandingkan sebelum adanya perlakuan (pretest). Hal itu sama dengan pendapat dari Sulaiman (2013), penggunaan media permainan congklak mampu meningkatkan hasil belajar siswa.

\section{Simpulan dan Saran}

Berdasarkan hasil penelitian, pembahasan dan analisis yang dilakukan oleh peneliti, maka peneliti dapat menyimpulkan bahwa: 1) Peningkatan rata-rata kemampuan berhitung siswa Kelas II SD Inpres Wosia setelah diberikan perlakuan dengan menggunakan media congklak. 2) Media congklak dapat meningkatkan kemampuan berhitung siswa Kelas II SD Inpres Wosia; 3) Media Congklak sangat membantu siswa memahami konsep matematika dan aplikasi secara baik.

Dari hasil penelitian ini disarankan kepada: 1) Guru hendaknya menggunakan media congklak dalam meningkatkan kemampuan berhitung siswa. 2) Guru harus lebih kreatif lagi dalam pembelajaran dengan mengunakan berbagai media permainan yang variatif. 3) Guru maupun kepala sekolah hendaknya memperhatikan mutu pendidikan untuk meningkatkan hasil belajar siswa. 4) Guru dan orang tua harus memberikan stimulus untuk perkembangan otak, salah satunya dengan memilihkan permainan yang tepat bagi siswa. 


\section{Daftar Rujukan}

Djamarah , Syaiful Bahri. 2011. Psikologi Belajar. Jakarta: Bumi Aksara. p107.

Fathurrohman Pupuh, Sutikno M Sobry. (2014). Strategi Belajar Mengajar Melalui Pemahaman Konsep Umum \& Konsep Islami. Bandung: Refika Adimata. p65.

Hidayat Asep. (2016). Pengaruh Penggunaan alat Peraga Dakon Matematika (Dakota) Terhadap Hasil Belajar Matematika Siswa. Jakarta: Universitas Islam Negeri Syarif Hidayatullah. http://repository.uinjkt.ac.id/dspace/bitstream/123456789/33756. 12(9). p1.

Kurniawati. (2006). Permainan Tradisional di Indonesia. Bandung: Rosdakarya. p7-10.

Michel, N., Cater III. J. J \& Varela, O. (2009). Active Versus Passive Teacing Styles: An Empirical Study Of Student Outcomes. Human Resource Development Quarterly. 20(4). P297-418.

Morena Cindo. (2010). Permainan Tradisonal. Jakarta: Ghina Walafa. p5.

Muksin Ahmadi. (2006). Bermain dan Kecerdasan Matematis. Bandung: Remaja Rosdakarya. p31.

Nataliaya Prima. (2015). Efektivitas Penggunaan Media Pembelajaran Permainan Tradisional Congklak Untuk Meningkatkan Kemampuan Berhitung Pada Siswa Sekolah Dasar. Jurnal Ilmiah Psikologi Terapan. 20(10). P246-353.

Sulaiman, A. (2013) Penerapan Media Permainan Dakon Dalam Peningkatan Hasil Belajar Berhitung Siswa Kelas I SD Al-Amin Surabaya. http://www.scribd.com/doc/125237696/PENERAPANMEDIAPERMAINAN-DAKON-DALAM-PENINGKATAN-HASIL-BELAJARBERHITUNG-SISWA-KELAS1-SD-AL-AMIN-SURABAYA\#scribd. 20(1).

Undang-Undang Nomor 20 Tahun 2003 tentang Sistem Pendidikan Nasional. Jakarta: Sinar Grafika .

Zubaidah Amir, Risnawati. (2006). Psikologi Pembelajaran Matematika. Yogyakarta: Aswajaja Pressindo. p63. 